\title{
Agrotechnical Biofortification as a Method to Increase Selenium Content in Spring Wheat
}

\author{
Aleksandra Radawiec*, Wiesław Szulc * and Beata Rutkowska
}

Citation: Radawiec, A.; Szulc, W.; Rutkowska, B. Agrotechnical Biofortification as a Method to Increase Selenium Content in Spring Wheat. Agronomy 2021, 11, 541. https://doi.org/10.3390/ agronomy11030541

Academic Editors:

Massimiliano D'Imperio,

Francesco Serio, Francesco Di Gioia, Agnieszka Sękara and Carla Sancho dos Santos

Received: 16 February 2021

Accepted: 11 March 2021

Published: 12 March 2021

Publisher's Note: MDPI stays neutra with regard to jurisdictional claims in published maps and institutional affiliations.

Copyright: (C) 2021 by the authors Licensee MDPI, Basel, Switzerland. This article is an open access article distributed under the terms and conditions of the Creative Commons Attribution (CC BY) license (https:/ / creativecommons.org/licenses/by/ $4.0 /)$.
Independent Department of Agricultural Chemistry, Institute of Agriculture, Warsaw University of Life Sciences, Nowoursynowska 166, 02-787 Warsaw, Poland; beata_rutkowska@sggw.edu.pl

* Correspondence: aleksandra_kowalczyk@sggw.edu.pl (A.R.); wieslaw_szulc@sggw.edu.pl (W.S.)

Abstract: Selenium (Se) is a micronutrient that is insufficiently present in the human diet. Increasing its content in food through appropriately matched agricultural practices may contribute to reducing Se deficit in humans. The study covered the effect of grain, soil, as well as grain and soil fertilization with selenium combined with foliar application at different stages of spring wheat (Triticum aestivum L.) development. The fertilization involved the application of sodium selenate. Fertilization with selenium had no significant effect on the grain yield. Grain application, soil application, and grain and soil application combined with foliar application at particular development stages of the plant significantly contributed to an increase in selenium content in grain. The study showed that the accumulation of selenium in spring wheat depends on the type of fertilization and term of its application. The best method of introducing selenium into the plant is grain and soil fertilization combined with foliar application at the stage of tillering and stem elongation $(G+S+F 1-2)$ for which the highest selenium content was obtained $\left(0.696 \mathrm{mg} \cdot \mathrm{kg}^{-1} \mathrm{Se}\right)$. The applied biofortification methods contributed to the increase in selenium in the grain of spring wheat.

Keywords: selenium; wheat; biofortification; grain; fertilization

\section{Introduction}

Selenium (Se) is an element that has gained interest of the scientific world in recent years. It is a microelement necessary for the life of humans and animals due to the functions that it fulfils in the organism. The course of physiological processes, however, is only optimal when the demand for the element is met within a certain range. Both selenium deficit and excess can lead to numerous disorders [1]. Dietary deficiency occurs at Se doses $<40 \mu \mathrm{g} \cdot \mathrm{day}^{-1}$, while toxicity is observed at doses $>400 \mu \mathrm{g} \cdot \mathrm{day}^{-1}$ Se [2,3]. Excess selenium, although very rare, can be harmful to human health [4-6]. Its main symptoms are usually garlic mouth odor, hair loss, nail plate decolorization, diarrhea, and neurological disorders. Selenium poisoning has been found to lead to: liver cirrhosis, pulmonary edema, and death. In addition, diabetes may be an adverse effect of long-term Se supplementation [7]. Selenium in appropriate amounts in the organism regulates the metabolism of thyroid hormones, participates in DNA synthesis, supports the cardio-vascular and immunological system, and provides protection against free radicals [8]. Se also mitigates the effects of poisoning with trace elements [9]. Selenium intake of 50-200 $\mu \mathrm{g} \cdot \mathrm{day}^{-1}$ for adults is considered safe and sufficient [10]. Its deficit has an unfavorable effect on the health of the animal and human organism [11-13]. The best-known examples of dietary Se deficiency are dilated cardiomyopathy (Keshan disease) [11,14] and osteoarthritis (Kashin-Beck disease) $[15,16]$. However, even a small deficiency of Se has negative effects on human health, such as increasing the risk of cancer, infertility in men, and neurological diseases [17-21].

Food is the basic source of selenium for people. Due to this, plants play an important role in supplementation with this element [22]. Selenium in plants is not considered to have important functions [23]. One can find information about the beneficial effects of Se on plant metabolism mainly related to plant stress resistance [24,25] and antioxidant 
functions. Other studies have also shown the role of selenium in extending the period to plant consumption [26].

There is a strong relationship between Se content in soil and the content in plants [27]. Low Se content in the soil in a major portion of land around the globe results in its proportionately insufficient content in the harvests of cultivated plants [28-30]. Due to this, in many countries in the world, mean selenium consumption does not cover the daily demand for this element in the organism [31,32]. Selenium deficiency affects approximately one billion people [33-35]. Furthermore, micronutrient deficiencies have been found to cause not only serious health problems, but also a significant economic burden on the health care system. The consequences of hidden hunger, as long-term deficiencies of elements in the body are termed, can cost on average about $5 \%$ of the gross domestic product [36,37]. Agricultural systems designed in the past did not set out to achieve better human health. The main goal was to produce as much food as possible to avoid starvation. In the context of hidden hunger, in order to counteract elemental deficiencies in the diet, a search for possibilities of their introduction into food products has begun [38]. One of such methods is agricultural biofortification, defined as a process of enriching edible parts of plants in desirable elements through appropriate agrotechnical treatments [39,40]. Agronomic biofortification is an effective and sustainable strategy to increase natural micronutrient intake in the human population, including selenium [41,42]. An excellent example is Finland, which, through the introduction of selenium as a fertilizer additive, has contributed to a targeted increase in selenium in the population [43]. In Brazil also, due to the low Se content in soils, an ordinance was introduced to allow the addition of Se in fertilizers in the country [44]. The demand for increasing selenium intake raises the need for new research to select the best strategy to increase Se in plants in order to obtain high quality food and thus ensure Se food security $[45,46]$.

Cereals are particularly predisposed for agricultural biofortification. Although they are not the primary source of selenium, their consumption contributes to its greatest supply in the human organism in the majority of countries around the globe [47]. Selenium content in cereal grain can be very variable, even within a range from 10 to $3000 \mu \mathrm{g} \cdot \mathrm{kg}^{-1}$ fresh mass. Cereal products cover approximately $70 \%$ of daily demand for the element in China, approximately $40-50 \%$ in India, and $18-24 \%$ in Great Britain [48]. In developing countries (Central Asia and Near East), wheat constitutes approximately half of daily energy consumption [41]. This suggests its vast nutritional importance. It is the primary cereal used for consumption and feedstuffs [49]. Wheat is considered to be a suitable crop for biofortification [50].

Due to the high health importance and the low supply of selenium, many studies have been undertaken to increase its content in food products. Successful experiments have been carried out to enrich plants such as wheat [51], rice [52], potato [53], cabbage [54], broccoli [55], carrot [56], lentils [57], alfalfa [58], etc. In order to better understand the relationship between Se in the environment and daily consumption, selenium supply, uptake by plants, and its impact on human health were reviewed $[10,30,59]$. Areas naturally rich in selenium (natural biofortification) were also used in the production of selenium enriched food in South Dakota [60], California [55] or India [61]. Both selenate (VI) and selenite (IV) were used as the main compound [62]. It was found that selenate is taken up and absorbed much faster [63], because selenite is strongly absorbed by chemical compounds in the soil, which reduces its mobility and uptake by plants [64]. Moreover, selenite has a tendency to accumulate in the roots, it is characterized by limited translocation by plants, while selenate is very mobile in xylem [65]. Particular attention was paid to the biofortification of wheat, which is the basic cereal for the production of bread. The research showed that fertilization with selenium increases the grain content in wheat $[66,67]$ and sometimes the grain yield [68-70]. Various types of fertilization were used: soil fertilization [71,72], foliar fertilization [40,68], grain fertilization [73], fertigation [62], and enriched plant material as green fertilizer [74]. On the other hand, no studies have been found that test the effect of many different combinations of fertilization applied in many different 
development phases separately and in combination. Therefore, it was hypothesized that the effectiveness of agronomic biofortification depends on the method of application and the development phase of the plant.

The study objective was the assessment of the effect of different ways of fertilization with selenium in the form of sodium selenate and date of application on the content of the element in spring wheat (Triticum aestivum L.) grain.

\section{Materials and Methods}

\subsection{Study Area}

The experiment was conducted in 2018 and 2019 at the Experimental Station of the Institute of Agriculture of the Warsaw University of Life Sciences in Skierniewice $\left(51^{\circ} 57^{\prime} 535 \mathrm{~N}, 20^{\circ} 9^{\prime} 254 \mathrm{E}\right)$ presented in Figure 1 . Weather conditions are presented in Table 1. According to the Köppen-Geiger climatic classification [75], the research area is located in the climate zone of a humid continental climate with mild summers and rainfall all year round.

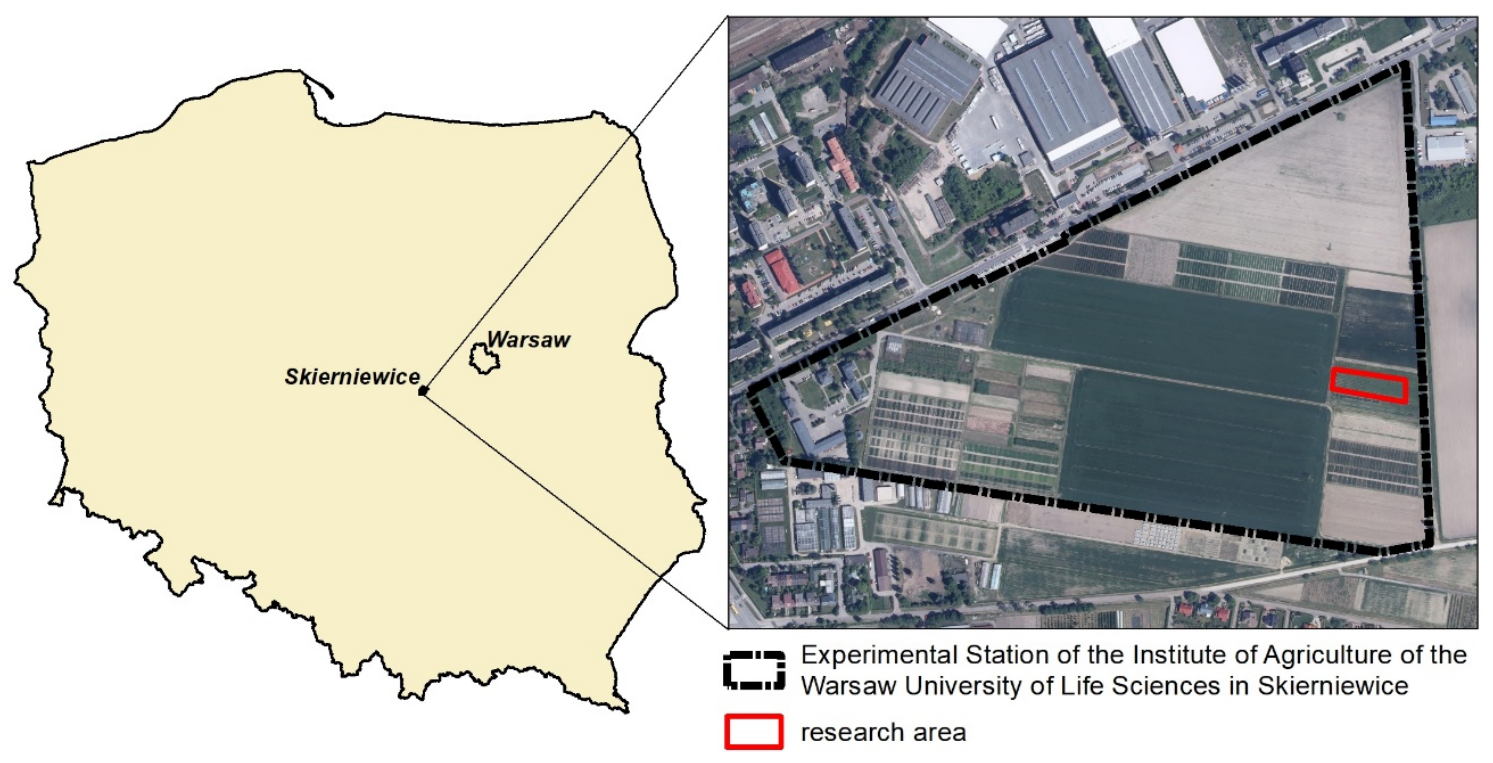

Figure 1. Location of the research area in Experimental Station of the Institute of Agriculture of the Warsaw University of Life Sciences in Skierniewice.

Table 1. Monthly precipitation totals and temperature in 2018 and 2019.

\begin{tabular}{ccccc}
\hline \multirow{2}{*}{ Months } & \multicolumn{2}{c}{$\mathbf{2 0 1 8}$} & \multicolumn{2}{c}{$\mathbf{2 0 1 9}$} \\
\cline { 2 - 5 } & $\begin{array}{c}\text { Precipitation } \\
{[\mathbf{m m}]}\end{array}$ & $\begin{array}{c}\text { Air Temperature } \\
{\left[{ }^{\circ} \mathbf{C}\right]}\end{array}$ & $\begin{array}{c}\text { Precipitation } \\
{[\mathbf{m m}]}\end{array}$ & $\begin{array}{c}\text { Air Temperature } \\
{\left[{ }^{\circ} \mathbf{C}\right]}\end{array}$ \\
\hline JAN & 28.1 & 1.0 & 36.0 & -1.6 \\
FEB & 9.7 & -3.4 & 34.7 & 3.2 \\
MAR & 23.6 & 0.4 & 34.2 & 6.2 \\
APR & 28.0 & 13.2 & 11.9 & 9.8 \\
MAY & 53.5 & 17.0 & 47.5 & 13.2 \\
JUN & 25.2 & 18.7 & 24.1 & 22.0 \\
JUL & 158.4 & 20.6 & 64.3 & 19.0 \\
AUG & 42.2 & 20.3 & 69.5 & 20.1 \\
SEP & 66.6 & 15.3 & 79.1 & 14.0 \\
OCT & 45.7 & 9.7 & 21.6 & 10.4 \\
NOV & 11.5 & 4.2 & 13.6 & 6.0 \\
DEC & 53.4 & 1.8 & 34.2 & 0.6 \\
\hline
\end{tabular}


The research was carried out on Luvisol soil experimental plots [76] with an area of $16.5 \mathrm{~m}^{2}$ [77]. The $\mathrm{pH}$ of the soil determined in 1-mol $\mathrm{KCl}$ by the potentiometric method on an automatic $\mathrm{pH}$ meter (Moga, Poland) was 4.97. It is a sandy acidic soil. Total content in soil of nitrogen $(\mathrm{N})$ by the Kjeldahl method was $0.76 \mathrm{~g} \cdot \mathrm{kg}^{-1}$, carbon $(\mathrm{C})$ determined on the Vario Max analyzer (Elementar, Germany) was $8.40 \mathrm{~g} \cdot \mathrm{kg}^{-1}$, and sulphur (S) determined by the same method was $0.33 \mathrm{~g} \cdot \mathrm{kg}^{-1}$, phosphorus $(\mathrm{P})$ determined by the Egner-Riehm method was $45.57 \mathrm{mg} \cdot \mathrm{kg}^{-1}$, and potassium $(\mathrm{K})$ determined by the same method was $150 \mathrm{mg} \cdot \mathrm{kg}^{-1}$. Total selenium (Se) content in the soil was determined by mineralization in aqua regia [78], then determined by atomic absorption spectrometry (AAS) using the Thermo Electronic SOLAAR M6 (Thermo Scientific, Wilmington, NC, USA). Selenium content in soil was $0.128 \mathrm{mg} \cdot \mathrm{kg}^{-1}$.

The plant used for the study was spring wheat Triticum aestivum L., the cv. Mandaryna. The sowing was done with the Poznaniak seeder. The seeding density was 5 million grains per ha. Mineral fertilization was applied on all plots at the following doses: $120 \mathrm{~kg} \mathrm{~N} \cdot \mathrm{ha}^{-1}$ in the form of urea $\left(\mathrm{CO}\left(\mathrm{NH}_{2}\right)_{2}\right), 35 \mathrm{~kg} \mathrm{P} \cdot \mathrm{ha}^{-1}$ in the form of calcium dihydrogen phosphate $\left(\mathrm{Ca}\left(\mathrm{H}_{2} \mathrm{PO}_{4}\right)_{2}\right)$, and $100 \mathrm{~kg} \mathrm{~K} \cdot \mathrm{ha}^{-1}$ in the form of potassium chloride $(\mathrm{KCl})$. The research was conducted in three replications. Comprehensive chemical protection in appropriate growth stages was used. To precisely define the stage of development, a scale was used, the abbreviation of which comes from the German Biologische Bundesanstalt, Bundessortenamt und Chemische Industrie (BBCH scale). Comprehensive chemical protection-seed dressing Oxafun T 75 DS/WS, herbicides Chwastox Trio 540 SL and Puma Uniwersal $069 \mathrm{EW}\left(1.2 \mathrm{dm}^{3} \cdot \mathrm{ha}^{-1}\right.$-BBCH 24-25), Alert $375 \mathrm{SC}$ fungicide $\left(1.0 \mathrm{dm}^{3} \cdot \mathrm{ha}^{-1}\right.$-BBCH 41-49) and insecticide Decis $2.5 \mathrm{EC}\left(250 \mathrm{~cm}^{3} \cdot \mathrm{ha}^{-1}-\mathrm{BBCH} 61-69\right)$.

Selenium was introduced in the form of sodium selenate $\left(\mathrm{Na}_{2} \mathrm{SeO}_{4}\right)$. The following types of fertilization with selenium were applied: grain application $(G)$, soil application $(S)$, and combined grain and soil application $(G+S)$ (Table 2). Grain application was performed through soaking spring wheat grains in $50.00 \mu \mathrm{mol}$ selenium solution for $24 \mathrm{~h}$ before seeding. Soil fertilization at a dose of $5.00 \mathrm{~g} \mathrm{Se} \cdot \mathrm{ha}^{-1}$ was applied before wheat seeding (spraying volume per hectare: $300 \mathrm{~L}$ ). Moreover, for each fertilization variant, foliar fertilization (F) was applied at a dose of $5.00 \mathrm{~g} \mathrm{Se} \cdot \mathrm{ha}^{-1}$ (spraying volume per hectare was $300 \mathrm{~L}$ ) at different development growth stages of the plant: F1-tillering (BBCH 22), F2 - stem elongation (BBCH 32), F3 - inflorescence emergence (BBCH 52), and F4-ripening (BBCH 85). Moreover, foliar fertilization treatments were applied at several development stages combined, where the total fertilizer dose $\left(5.00 \mathrm{~g} \mathrm{Se} \cdot \mathrm{ha}^{-1}\right)$ was divided into the number of selenium applications: F1-2 - tillering and stem elongation, F1-3 - tillering, stem elongation, and inflorescence emergence, as well as F1-4-tillering, stem elongation, inflorescence emergence, and ripening stage.

\subsection{Sampling and Analysis}

After the harvest, the grain was weighed, and then, the samples of material were dried at $50{ }^{\circ} \mathrm{C}$ with forced air circulation, then at $105^{\circ} \mathrm{C}$ to constant weight [79], and ground using a mill (Retsh, Katowice, Poland) at $5000 \mathrm{rpm}$. The content of selenium in the grain was determined after mineralization in the mixture of $\mathrm{HNO}_{3}$ and $\mathrm{HClO}_{4}$, through the method of atomic absorption spectrometry (AAS), using the Thermo Elemental SOLAAR M6 apparatus (Thermo Scientific, Wilmington, NC, USA).

The statistical analyses were performed by means of the Statgraphics 5.1. software (The Plains, VA, USA). The results were subject to single factor and multivariate analysis of variance ANOVA and $t$-test at a significance level of $p=0.05$, and Pearson linear correlation analysis. 
Table 2. Research scheme.

\begin{tabular}{|c|c|c|c|}
\hline Treatment & & Dose of Se & Total Dose of Se \\
\hline Control & $\mathrm{C}$ & 0.00 & 0.00 \\
\hline Grain application & G & $50.00 \mu \mathrm{mol}$ grain & $50.00 \mu \mathrm{mol}$ \\
\hline Soil application & S & $5.00 \mathrm{~g} \cdot \mathrm{ha}^{-1}$ soil & $5.00 \mathrm{~g} \cdot \mathrm{ha}^{-1}$ \\
\hline Grain and soil application & $G+S$ & $50.00 \mu \mathrm{mol}$ grain $+5.00 \mathrm{~g} \cdot \mathrm{ha}^{-1}$ soil & $50.00 \mu \mathrm{mol}+5.00 \mathrm{~g} \cdot \mathrm{ha}^{-1}$ \\
\hline \multirow[t]{4}{*}{$\begin{array}{l}\text { Grain and foliar application } \\
(G+F)\end{array}$} & $\begin{array}{l}G+F 1 \\
G+F 2 \\
G+F 3 \\
G+F 4\end{array}$ & $\begin{array}{l}50.00 \mu \mathrm{mol} \text { grain }+5.00 \mathrm{~g} \cdot \mathrm{ha}^{-1} \text { foliar } \\
50.00 \mu \mathrm{mol} \text { grain }+5.00 \mathrm{~g} \cdot \mathrm{ha}^{-1} \text { foliar } \\
50.00 \mu \mathrm{mol} \text { grain }+5.00 \mathrm{~g} \cdot \mathrm{ha}^{-1} \text { foliar } \\
50.00 \mu \mathrm{mol} \text { grain }+5.00 \mathrm{~g} \cdot \mathrm{ha}^{-1} \text { foliar }\end{array}$ & $\begin{array}{l}50.00 \mu \mathrm{mol}+5.00 \mathrm{~g} \cdot \mathrm{ha}^{-1} \\
50.00 \mu \mathrm{mol}+5.00 \mathrm{~g} \cdot \mathrm{ha}^{-1} \\
50.00 \mu \mathrm{mol}+5.00 \mathrm{~g} \cdot \mathrm{ha}^{-1} \\
50.00 \mu \mathrm{mol}+5.00 \mathrm{~g} \cdot \mathrm{ha}^{-1}\end{array}$ \\
\hline & $\mathrm{G}+\mathrm{F} 1-2$ & $\begin{array}{l}50.00 \mu \mathrm{mol} \text { grain }+2.5 \mathrm{~g} \cdot \mathrm{ha}^{-1} \text { foliar in each } \\
\text { treatment }\end{array}$ & $50.00 \mu \mathrm{mol}+5.00 \mathrm{~g} \cdot \mathrm{ha}^{-1}$ \\
\hline & $G+F 1-3$ & $\begin{array}{l}50.00 \mu \mathrm{mol} \text { grain }+1.67 \mathrm{~g} \cdot \mathrm{ha}^{-1} \text { foliar in each } \\
\text { treatment }\end{array}$ & $50.00 \mu \mathrm{mol}+5.00 \mathrm{~g} \cdot \mathrm{ha}^{-1}$ \\
\hline & $G+F 1-4$ & $\begin{array}{l}50.00 \mu \mathrm{mol} \text { grain }+1.25 \mathrm{~g} \cdot \mathrm{ha}^{-1} \text { foliar in each } \\
\text { treatment }\end{array}$ & $50.00 \mu \mathrm{mol}+5.00 \mathrm{~g} \cdot \mathrm{ha}^{-1}$ \\
\hline \multirow{7}{*}{$\begin{array}{l}\text { Grain and soil application } \\
\text { combined with foliar } \\
\text { application }(G+S+F)\end{array}$} & $\mathrm{G}+\mathrm{S}+\mathrm{F} 1$ & $\begin{array}{l}50.00 \mu \mathrm{mol} \text { grain }+5.00 \mathrm{~g} \cdot \mathrm{ha}^{-1} \text { soil }+5.00 \mathrm{~g} \cdot \mathrm{ha}^{-1} \\
\text { foliar }\end{array}$ & $50.00 \mu \mathrm{mol}+10.00 \mathrm{~g} \cdot \mathrm{ha}^{-1}$ \\
\hline & $\mathrm{G}+\mathrm{S}+\mathrm{F} 2$ & $\begin{array}{l}50.00 \mu \mathrm{mol} \text { grain }+5.00 \mathrm{~g} \cdot \mathrm{ha}^{-1} \text { soil }+5.00 \mathrm{~g} \cdot \mathrm{ha}^{-1} \\
\text { foliar }\end{array}$ & $50.00 \mu \mathrm{mol}+10.00 \mathrm{~g} \cdot \mathrm{ha}^{-1}$ \\
\hline & $\mathrm{G}+\mathrm{S}+\mathrm{F} 3$ & $\begin{array}{l}50.00 \mu \mathrm{mol} \text { grain }+5.00 \mathrm{~g} \cdot \mathrm{ha}^{-1} \text { soil }+5.00 \mathrm{~g} \cdot \mathrm{ha}^{-1} \\
\text { foliar }\end{array}$ & $50.00 \mu \mathrm{mol}+10.00 \mathrm{~g} \cdot \mathrm{ha}^{-1}$ \\
\hline & $\mathrm{G}+\mathrm{S}+\mathrm{F} 4$ & $\begin{array}{l}50.00 \mu \mathrm{mol} \text { grain }+5.00 \mathrm{~g} \cdot \mathrm{ha}^{-1} \text { soil }+5.00 \mathrm{~g} \cdot \mathrm{ha}^{-1} \\
\text { foliar }\end{array}$ & $50.00 \mu \mathrm{mol}+10.00 \mathrm{~g} \cdot \mathrm{ha}^{-1}$ \\
\hline & $\mathrm{G}+\mathrm{S}+\mathrm{F} 1-2$ & $\begin{array}{l}50.00 \mu \text { mol grain }+5.00 \mathrm{~g} \cdot \mathrm{ha}^{-1} \text { soil }+2.50 \mathrm{~g} \cdot \mathrm{ha}^{-1} \\
\text { foliar in each treatment }\end{array}$ & $50.00 \mu \mathrm{mol}+10.00 \mathrm{~g} \cdot \mathrm{ha}^{-1}$ \\
\hline & $\mathrm{G}+\mathrm{S}+\mathrm{F} 1-3$ & $\begin{array}{l}50.00 \mu \mathrm{mol} \text { grain }+5.00 \mathrm{~g} \cdot \mathrm{ha}^{-1} \text { soil }+1.67 \mathrm{~g} \cdot \mathrm{ha}^{-1} \\
\text { foliar in each treatment }\end{array}$ & $50.00 \mu \mathrm{mol}+10.00 \mathrm{~g} \cdot \mathrm{ha}^{-1}$ \\
\hline & $\mathrm{G}+\mathrm{S}+\mathrm{F} 1-4$ & $\begin{array}{l}50.00 \mu \text { mol grain }+5.00 \mathrm{~g} \cdot \mathrm{ha}^{-1} \text { soil }+1.25 \mathrm{~g} \cdot \mathrm{ha}^{-1} \\
\text { foliar in each treatment }\end{array}$ & $50.00 \mu \mathrm{mol}+10.00 \mathrm{~g} \cdot \mathrm{ha}^{-1}$ \\
\hline
\end{tabular}

F1-application at the tillering stage (BBCH 22), F2-application at the stem elongation stage (BBCH 32), F3—application at the inflorescence emergence stage (BBCH 52), F4-application at the ripening stage (BBCH 85), F1-2 -application at the stage of tillering and stem elongation, F1-3-application at the stage of tillering, stem elongation, and inflorescence emergence, F1-4-application at the stage of tillering, stem elongation, inflorescence emergence, and ripening.

\section{Results}

\subsection{Average Yield of Wheat Grain}

This paper presents yield results for spring wheat from two years. The grain yield differed from one year to the next (Table 3). The main influence on the yield was mainly due to weather conditions. However, this did not affect the direct aim of the study. In 2018, although precipitation was higher than in 2019, an unfavorable distribution was found in terms of plant vegetation. As a result, wheat accelerated its development and entered the earing stage faster, as a result, a relatively low grain yield was obtained. On the other hand, in 2019, low rainfall contributed to the low yield of wheat grain.

Mean grain yield from two years for the control object (C) was $1.79 \pm 0.415 \mathrm{t} \cdot \mathrm{ha}^{-1}$, and in the case of combined fertilization with selenium, the value varied from 1.57 to $2.15 \mathrm{t} \cdot \mathrm{ha}^{-1}$. The lowest yield was obtained for grain application combined with foliar application at the stage of tillering, stem elongation, and inflorescence emergence $(\mathrm{G}+\mathrm{F} 1-3)$, where the yield mass was approximately $12.29 \%$ lower in comparison to control. The highest yield was recorded in the case of grain fertilization combined with foliar application at the stage of tillering and stem elongation $(G+F 1-2)$, where the yield mass was approximately $20.11 \%$ higher than control sample. No significant effect of fertilization with selenium on grain yield was determined. The first year of the study was characterized by a considerably higher yield in comparison to the second year of the study (Figure 2). 
No correlation was determined between yield and selenium content in wheat grain either in the first or the second year of the study.

Table 3. The influence of experimental factors on the selenium content in grain and the yield.

\begin{tabular}{lcc}
\hline Experience Factor & Selenium & Yield \\
\hline year & 0.702 & 0.000 \\
fertilization & 0.003 & 0.583 \\
application time & 0.000 & 0.107 \\
year * fertilization & 0.108 & 0.213 \\
year* application time & 0.527 & 0.974 \\
fertilization * application time & 0.120 & 0.914 \\
year * fertilization * application time & 0.810 & 0.993 \\
\hline
\end{tabular}

Significant difference ${ }^{*}$ for $p<0.05$ based on multivariate ANOVA.

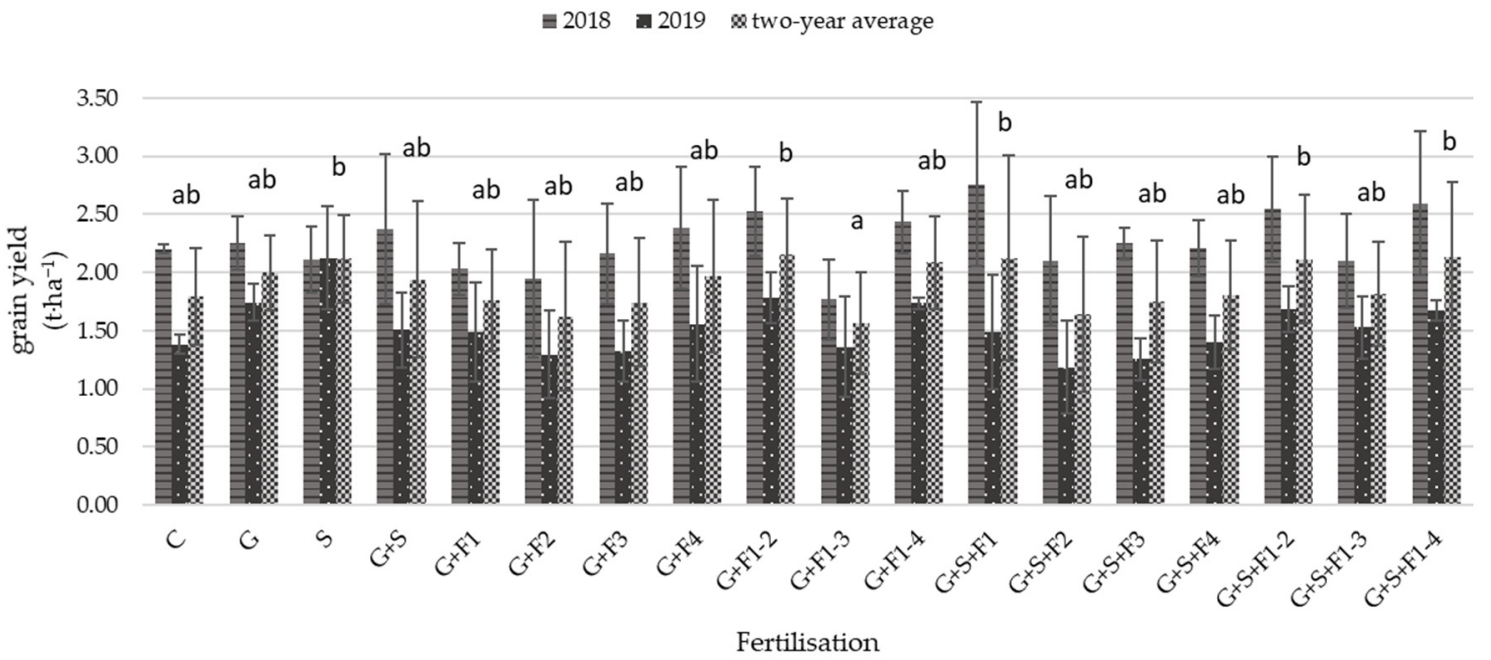

Figure 2. Average grain yield as a function of fertilization $\left(t \cdot h a^{-1}\right)$ and homogeneous groups for the average yield of two years. Values are mean \pm standard error. $a, b, c-$ Means followed by the same letter are not significantly different from one another based on Tukey's test at $p \leq 0.05$.

\subsection{Selenium Content in Grain}

Mean selenium content in grain for the control object (C) from two years was $0.187 \pm$ $0.049 \mathrm{mg} \cdot \mathrm{kg}^{-1}$ and was the lowest (Figure 3). Both fertilization and the time of application influenced the selenium content in the grain (Table 3). All objects fertilized with selenium showed higher content of the element in grain, varying from 0.211 to $0.696 \mathrm{mg} \cdot \mathrm{kg}^{-1}$ selenium in grain, resulting in an approximately 0.1 to more than 2.7 -fold increase in selenium content in comparison to the control object. Selenium content in grain in the case of grain $(\mathrm{G})$ and soil application $(\mathrm{S})$ showed no significant differences. Combined application of both types of fertilization $(\mathrm{G}+\mathrm{S})$ resulted in higher selenium content in grain $\left(0.396 \mathrm{mg} \cdot \mathrm{kg}^{-1} \mathrm{Se}\right)$. Among the fertilized objects, the highest content of this element was found in the case of grain and soil application together with foliar application at the tillering and stem elongation stages $(\mathrm{G}+\mathrm{S}+\mathrm{F} 1-2)$. High selenium content was also found in the case of grain and soil application combined with foliar application at the stage of stem elongation (G + S + F2), where $0.481 \pm 0.169 \mathrm{mg} \cdot \mathrm{kg}^{-1}$ Se was obtained. The least effective was the grain application together with foliar application at the stage of ripening $(G+F 4)$ and grain and soil fertilization together with foliar application at the stages of tillering, stem elongation, inflorescence emergence, and ripening ( $G+S+F 1-4)$. In this case, only about $13.40 \%$ increase of selenium content in grain was obtained compared to the 
control. Comparing the two years of the study, there was no significant difference between selenium content in the first and second year.

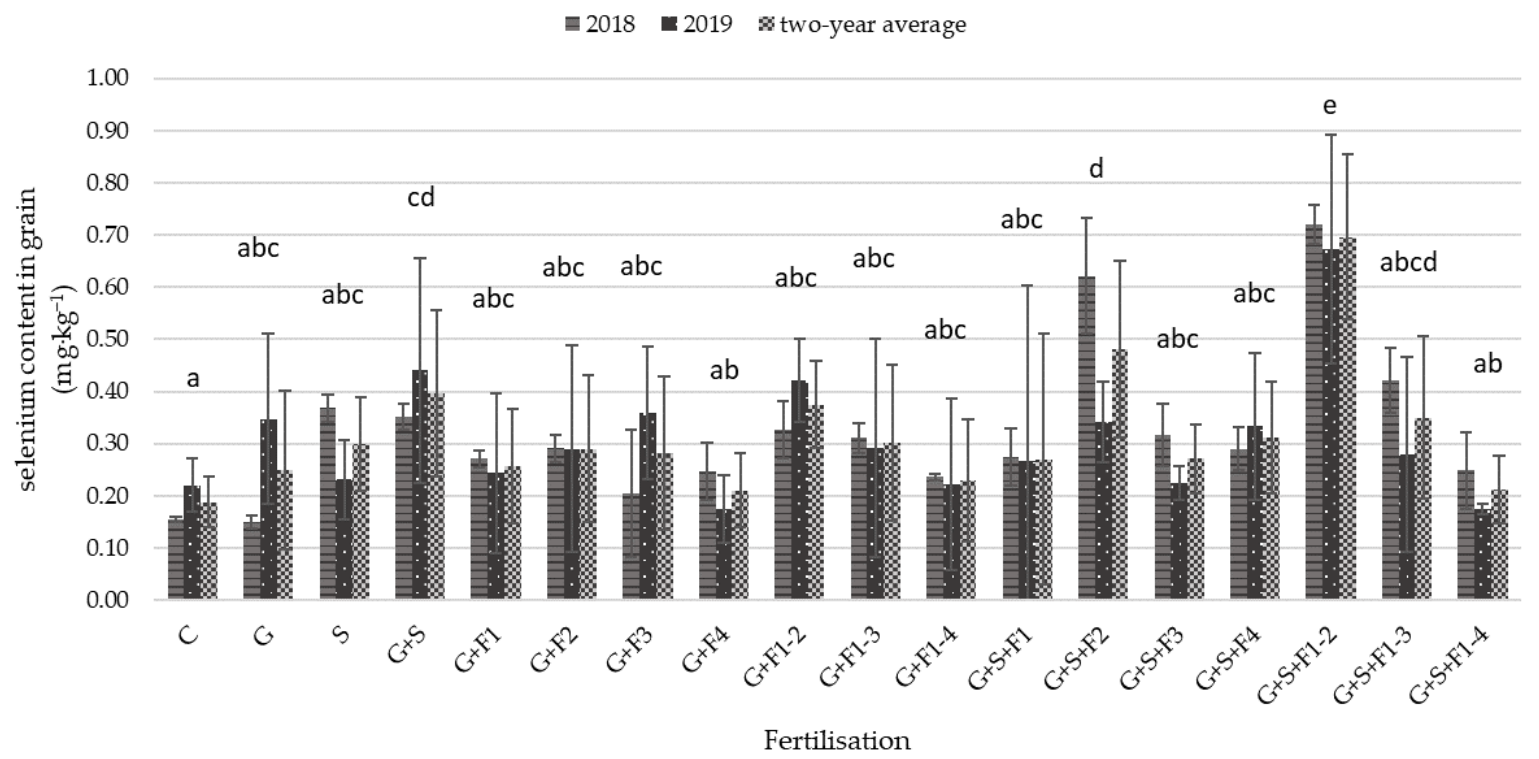

Figure 3. Average selenium content in grain depending on the type of fertilization, and homogenous groups for mean selenium content in grain from two years of the study. Values are mean \pm standard error. $a, b, c-$ Means followed by the same letter are not significantly different from one another based on Tukey's test at $p \leq 0.05$.

In the study conducted, the most effective method was grain and soil fertilization combined with foliar application at predetermined stages $(G+S+F)$. The grain and soil fertilization carried out separately did not cause an increase in selenium content in wheat grain as compared to the combination of the three methods. This is partly due to the combined application of a higher dose of selenium $\left(50.00 \mu \mathrm{mol} \mathrm{Se}\right.$ to grain, $5.00 \mathrm{~g} \cdot \mathrm{ha}^{-1}$ Se to soil, and $5.00 \mathrm{~g} \cdot \mathrm{ha}^{-1}$ Se as an additional foliar application). Comparative analysis of selenium fertilization doses, taking into account additional foliar application, showed that in the case of higher doses the selenium content in grain increased significantly for grain and soil fertilization combined with foliar fertilizer at tillering and stem elongation stage ( $\mathrm{G}+\mathrm{S}+\mathrm{F} 1-2)$. A significant difference was found only for the F1-2 combination, because these phases, mainly the stem elongation phase, are characterized by an increased demand for nutrients, which increases the absorption of selenium in this period. This allows to draw a conclusion that it is not only the amount of selenium supplied that determines the final selenium content in grain, but also the phase of development in which the element is introduced (Table 4).

Table 4. Average selenium content in wheat grain depending on dose and phase of foliar application.

\begin{tabular}{|c|c|c|c|}
\hline $\begin{array}{l}\text { Combination of Foliar } \\
\text { Application }\end{array}$ & $\begin{array}{c}\text { Dose } 50.00 \mu \mathrm{mol}+5.00 \\
\mathrm{~g} \cdot \mathrm{ha}^{-1} \mathrm{Se} \mathrm{G}+\mathrm{F}\end{array}$ & $\begin{array}{c}\text { Dose } 50.00 \mu \mathrm{mol}+10.00 \\
\mathrm{~g} \cdot \mathrm{ha}^{-1} \mathrm{Se} \\
\mathrm{G}+\mathrm{S}+\mathrm{F}\end{array}$ & $p$-Value \\
\hline $\mathrm{F} 1$ & 0.257 & 0.271 & 0.912 \\
\hline F2 & 0.290 & 0.481 & 0.081 \\
\hline F3 & 0.282 & 0.271 & 0.878 \\
\hline $\mathrm{F} 4$ & 0.211 & 0.311 & 0.109 \\
\hline F1-2 & 0.375 & 0.696 & 0.002 \\
\hline F1-3 & 0.302 & 0.350 & 0.626 \\
\hline F1-4 & 0.229 & 0.212 & 0.777 \\
\hline All experiment & 0.278 & 0.370 & 0.021 \\
\hline
\end{tabular}

$n=3$, significant difference for $p<0.05$ based on $t$-test. 


\section{Discussion}

Wheat shows a significant ability to take up selenium at higher levels without adversely affecting plant growth [80]. It is generally claimed that selenium is not a growthlimiting factor [81]. Many studies even indicate positive effects of selenium fertilization on crop yields [69,70,82]. On the other hand, Curtin et al. [83], in their study, obtained no significant differences in grain yield of wheat fertilized with two different selenium fertilizers (with fast and slow release of the element). Moreover, when high dose of selenium $\left(120 \mathrm{~g} \cdot \mathrm{ha}^{-1}\right)$ was applied, no higher yield was obtained [84]. Similarly, in the experiment conducted, no effect of fertilization with selenium on wheat grain yield was determined for the majority of combinations. Based on other studies, it can be concluded that the lack of effect of selenium fertilization on the wheat grain yield is a favorable side effect of agrotechnical biofortification. The selenium content of the soil is only $0.128 \mathrm{mg} \cdot \mathrm{kg}^{-1}$ Se. According to the classification of soils in terms of selenium abundance [85,86], it includes soils with marginal Se content $\left(0.125-0.175 \mathrm{mg} \cdot \mathrm{kg}^{-1}\right)$ where typical human selenium deficiency symptoms have been found in the past [59]. The low selenium content in the soil also translates into the lowest selenium content in wheat in the control sample. Fertilization with selenium contributed to increase selenium content in wheat grain. Thus, it can be concluded that the biofortification turned out to be effective. A significant effect of fertilization with selenium was presented also by Grant et al. [73], who introduced selenium in a wheat plantation through grain coating and soil application using granulated fertilizers, as well as foliar application. All methods of selenium introduction contributed to an increase in its content in grain, whereas foliar and grain application proved the most effective. In this study, among all the fertilization methods, combined fertilization (grain, soil and foliar) proved to be the most effective. It could be concluded that the most important factor is the dose of fertilization. However, analyses showed that using the same fertilization rate, while foliar application is introduced at different developmental stages of wheat, the selenium content in grain differs significantly.

Both in the case of grain application $(G+F)$ and soil application $(S+F)$ combined with foliar application, the highest selenium contents were observed for foliar application at the stage of tillering and stem elongation (F1-2). The highest of all selenium contents in grain was determined in the case for grain and soil application combined with foliar application at the stage of tillering and stem elongation $(G+S+F 1-2)$. Moreover, for the stem elongation stage $(\mathrm{G}+\mathrm{S}+\mathrm{F} 2)$, foliar application contributed to a doubling of selenium content in grain. Studies by Ramkinssoon [71] and Rodrigo et al. [87] confirmed this trend. This suggests that the best way to introduce selenium into the plant is grain and soil application supplemented with foliar application, whereas the best term for the treatment in spring wheat cultivation is the stage of tillering (BBCH 20-29) and stem elongation (BBCH 30-39). Similar conclusions were drawn by Curtin et al. [88]. According to their research, the best method of wheat fertilization aimed at selenium enrichment is foliar or soil application around growth stage 31 .

Application rates of 10.00 to $20.00 \mathrm{~g} \cdot \mathrm{ha}^{-1}$ Se can achieve biofortification goals [89,90]. Moreover, other studies evaluating the effect of applying Se from 0 to $25 \mathrm{~g} \cdot \mathrm{ha}^{-1}$ have shown increased Se in crops [91,92]. In this study, low doses of selenium were used (maximum dose was $50 \mu \mathrm{mol}+10 \mathrm{~g} \cdot \mathrm{ha}^{-1} \mathrm{Se}$ ), which did not contribute to excessive selenium content in grain compared to the above studies. The target range of selenium content in grain desired for biofortification at which there is no risk of toxic effects is from 0.1 to $1.0 \mathrm{mg} \cdot \mathrm{kg}^{-1}$ [93]. The conducted research allowed to obtain selenium content in grain within the above range. Moreover, when comparing the results of the study to sites with high selenium supply without toxic effect and at the same time desirable blood selenium content [92], they are similar. The highest value of selenium in grain, $0.696 \mathrm{mg} \cdot \mathrm{kg}^{-1} \mathrm{Se}$, was found for the total combination of all fertilization methods at the stage of tillering and stem elongation $(G+S+F 1-2)$. While fertilization with each method separately did not turn out to be effective, the combined method contributed to the desired amount of selenium content. This result demonstrate an effectively implemented agrotechnical biofortification aimed at 
increasing the grain content of wheat, without any toxic effects. The study conducted can help fertilizer manufacturers to determine the best fertilizers and Se levels to ensure the safety of Se inclusion in the food chain in the future, thereby improving the Se intake of the population.

\section{Conclusions}

The studies showed that the accumulation of selenium in spring wheat depends on the method of fertilization and the date of its application. The best method of introduction of selenium into the plant is grain and soil application combined with foliar application at the stage of tillering and stem elongation $(\mathrm{G}+\mathrm{S}+\mathrm{F} 1-2)$. Agrotechnical biofortification is a safe way to enrich plants with selenium in order to ensure higher quality food products in terms of food safety and quality.

Author Contributions: Conceptualization: A.R., W.S., and B.R.; methodology: W.S. and B.R.; validation: A.R. and W.S.; formal analysis: A.R. and W.S.; investigation: A.R.; resources: A.R., W.S., and B.R.; data curation: A.R.; writing—original draft preparation: A.R.; writing—review and editing: W.S. and B.R.; visualization: A.R., W.S., and B.R.; supervision: W.S. and B.R.; project administration: W.S.; funding acquisition: A.R. and W.S. All authors have read and agreed to the published version of the manuscript.

Funding: This research received no external funding.

Institutional Review Board Statement: Not applicable.

Informed Consent Statement: Not applicable.

Data Availability Statement: Data are available by contacting the authors.

Conflicts of Interest: The authors declare no conflict of interest.

\section{References}

1. Rayman, M.P. The importance of selenium to human health. Lancet 2000, 356, 233-241. [CrossRef]

2. Fairweather-Tait, S.J.; Bao, Y.; Broadley, M.R.; Collings, R.; Ford, D.; Hesketh, J.E.; Hurst, R. Selenium in human health and disease. Antioxid. Redox Signal. 2011, 14, 1337-1383. [CrossRef]

3. Vinceti, M.; Filippini, T.; Wise, L.A. Environmental Selenium and Human Health: An Update. Curr. Environ. Health. Rep. 2018, 5 , 464-485. [CrossRef] [PubMed]

4. Fordyce, F.M. Selenium deficiency and toxicity in the environment. In Essentials of Medical Geology; Springer: Dordrecht, The Netherlands, 2013; pp. 375-416.

5. Wu, Q.; Rayman, M.P.; Lv, H.; Schomburg, L.; Cui, B.; Gao, C.; Chen, P.; Zhuang, G.; Zhang, Z.; Peng, X.; et al. Low population selenium status is associated with increased prevalence of thyroid disease. J. Clin. Endocrinol. Metab. 2015, 100, 4037-4047. [CrossRef] [PubMed]

6. Lv, Q.; Liang, X.; Nong, K.; Gong, Z.; Qin, T.; Qin, X.; Wang, D.; Zhu, Y. Advances in Research on the Toxicological Effects of Selenium. Bull. Environ. Contam. Toxicol. 2021, 1-12. [CrossRef]

7. Ratajczak, M.; Gietka-Czernel, M. The role of selenium in the human body. Adv. Med. Sci. 2016, 12, 929-933. (In Polish)

8. Kieliszek, M.; Błażejak, S. Selenium: Significance, and outlook for supplementation. Nutrition 2013, 29, 713-718. [CrossRef]

9. Zhou, Y.J.; Zhang, S.P.; Liu, C.W.; Cai, Y.Q. The protection of selenium on ROS mediated-apoptosis by mitochondria dysfunction in cadmium-induced LLC-PK1 cells. Toxicol. Vitr. 2009, 23, 288-294. [CrossRef]

10. Sönmez, F. The Importance of Selenium Fertilization in Wheat. Available online: https://www.researchgate.net/profile/ Fatih_Cig2/publication/348351662_BREEDING_PHYSIOLOGY_QUALITY_FERTILIZATION_PRACTICE_PRODUCTIONS_ AND_IMPROVEMENT_CEREAL_GRAIN_CEREAL_GRAIN_PRODUCTIONS_AND_IMPROVEMENT_EDITOR/links/ 5ff9803745851553a02e93bb/BREEDING-PHYSIOLOGY-QUALITY-FERTILIZATION-PRACTICE-PRODUCTIONS-ANDIMPROVEMENT-CEREAL-GRAIN-CEREAL-GRAIN-PRODUCTIONS-AND-IMPROVEMENT-EDITOR.pdf\#page=174 (accessed on 12 January 2021).

11. Hou, J.; Wang, T.; Liu, M.; Li, S.; Chen, J.; Liu, C.; Zhang, H.; Wang, Y.; Liu, Z.; Liang, N.; et al. Suboptimal selenium supply-A continuing problem in Keshan disease areas in Heilongjiang province. Biol. Trace Elem. Res. 2011, 143, 1255-1263. [CrossRef]

12. Żarczynska, K.; Sobiech, P.; Radwinska, J.; Rekawek, W. Effects of selenium on animal health. J. Elem. 2013, 18, 330. [CrossRef]

13. Tardy, A.L.; Ballesta, A.A.; Yilmaz, G.C.; Dan, M.; Ramirez, D.M.; Lam, H.Y.; Azais-Braesco, V.; Pouteau, E. Adult's Dietary Intakes of Selected Vitamins \& Minerals Essential for Energy Metabolism and Cognition: A Comparison Across Countries \& Genders (FS10-04-19). Curr. Dev. Nutr. 2019, 3, 1501. [CrossRef] 
14. Li, Z.X.; Yang, L.; Wang, Y.B.; Zhao, S.; Huang, W.L.; Ma, L. Analysis of Keshan disease investigation result in Yunnan province in 2008. Chin. J. Endemiol. 2010, 29, 93-95.

15. Zhang, B.; Yang, L.; Wang, W.; Li, Y.; Li, H. Quantification and comparison of soil elements in the Tibetan plateau Kaschin-beck disease area: A case study in Zamtang County, Sichuan Province, China. Biol. Trace Elem. Res. 2010, 138, 69-78. [CrossRef]

16. Yang, C.; Yao, H.; Wu, Y.; Sun, G.; Yang, W.; Li, Z.; Shang, L. Status and risks of selenium deficiency in a traditional seleniumdeficient area in Northeast China. Sci. Total Environ. 2021, 762, 144103. [CrossRef] [PubMed]

17. Keskes-Ammar, L.; Feki-Chakroun, N.; Rebai, T.; Sahnoun, Z.; Ghozzi, H.; Hammami, S.; Zghal, K.; Fki, H.; Damak, J.; Bahloul, A. Sperm oxidative stress and the effect of an oral vitamin $\mathrm{E}$ and selenium suplement on semen quality in infertile men. Arch. Androl. 2003, 49, 83-94. [CrossRef] [PubMed]

18. Zhang, S.; Rocourt, C.; Cheng, W.H. Selenoproteins and the aging brain. Mech. Ageing Dev. 2010, 131, 253-260. [CrossRef] [PubMed]

19. Klecha, B.; Bukowska, B. Selenium in the human body-Characteristics of the element and potential therapeutic application. Bromatol. Toxicol. Chem. 2016, 4, 818-829. (In Polish)

20. Jones, G.D.; Droz, B.; Greve, P.; Gottschalk, P.; Poffet, D.; McGrath, S.P.; Seneviratne, S.I.; Smith, P.; Winkel, L.H. Selenium deficiency risk predicted to increase under future climate change. Proc. Natl. Acad. Sci. USA 2017, 11, 2848-2853. [CrossRef] [PubMed]

21. Chauhan, R.; Awasthi, S.; Srivastava, S.; Dwivedi, S.; Pilon-Smits, E.A.; Dhankher, O.P.; Tripathi, R.D. Understanding selenium metabolism in plants and its role as a beneficial element. Crit. Rev. Environ. Sci. Technol. 2019, 49, 1937-1958. [CrossRef]

22. Winkel, L.H.; Vriens, B.; Jones, G.D.; Schneider, L.S.; Pilon-Smits, E.; Bañuelos, G.S. Selenium cycling across soil-plant-atmosphere interfaces: A critical review. Nutrients 2015, 7, 4199-4239. [CrossRef] [PubMed]

23. Feng, R.; Wei, C.; Tud, S. The roles of selenium in protecting plants against abiotic stresses. Environ. Exp. Bot. 2013, 87, 58-68. [CrossRef]

24. Andrade, F.R.; Silva, G.N.; Guimarães, K.C.; Barreto, H.B.F.; Souza, K.R.D.; Guilherme, L.R.G.; Faquin, V.; Reis, A.R. Selenium protects rice plants from water deficit stress. Ecotoxicol. Environ. Saf. 2018, 164, 562-570. [CrossRef] [PubMed]

25. Yao, X.Q.; Chu, J.Z.; Ba, C.J. Antioxidant responses of wheat seedlings to exogenous selenium supply under enhanced ultraviolet-B. Biol. Trace Elem. Res. 2010, 136, 96-105. [CrossRef]

26. Zhu, Z.; Chen, Y.; Shi, G.Q.; Zhang, X. Selenium delays tomato fruit ripening by inhibiting ethylene biosynthesis and enhancing the antioxidant defense system. Food Chem. 2017, 219, 179-184. [CrossRef]

27. Liu, H.; Wang, X.; Zhang, B.; Han, Z.; Wang, W.; Chi, Q.; Zhou, J.; Nie, L.; Xu, S.; Liu, D.; et al. Concentration and distribution of selenium in soils of mainland China, and implications for human health. J. Geochem. Explor. 2021, 220, 106654. [CrossRef]

28. White, P.J.; Broadley, M.R. Biofortification of crops with seven mineral elements often lacking in human diets-iron, zinc, copper, calcium, magnesium, selenium and iodine. New Phytol. 2009, 182, 49-84. [CrossRef]

29. Lopes, A.; Ávila, F.W.; Guilherme, L.R.G. Selenium behavior in the soil environment and its implication for human health. Ciência Agrotecnologia 2017, 41, 605-615. [CrossRef]

30. Reis, A.; El-Ramady, H.; Santos, E.F.; Gratão, P.L.; Schomburg, L. Overview of selenium deficiency and toxicity worldwide: Affected areas, selenium-related health issues, and case studies. In Selenium in Plants; Springer: Gewerbestrasse, Switzerland, 2017; pp. 209-230.

31. Rayman, M.P. Selenium in cancer prevention: A review of the evidence and mechanism of action. Proc. Nutr. Soc. 2005, 64, 527-542. [CrossRef] [PubMed]

32. Saha, U.; Fayiga, A.; Sonon, L. Selenium in the soil-plant environment: A review. Int. J. Appl. Agric. Sci. 2017, 3, 1-18. [CrossRef]

33. Bailey, R.L.; West, K.P.; Black, R.E. The epidemiology of global micronutrient deficiencies. Ann. Nutr. Metab. 2015, 66, 22-33. [CrossRef]

34. Hefferon, K.L. Nutritionally enhanced food crops; progress and perspectives. Int. J. Mol. Sci. 2015, 16, 3895-3914. [CrossRef]

35. O'Hare, T.J. Biofortification of vegetables for the developed world. Acta Hortic. 2015, 1106, 1-8. [CrossRef]

36. Godecke, T.; Stein, A.J.; Qaim, M. The global burden of chronic and hidden hunger: Trends and determinants. Glob. Food Secur. 2018, 17, 21-29. [CrossRef]

37. Lenaerts, B.; Demont, M. The global burden of chronic and hidden hunger revisited: New panel data evidence spanning 1990-2017. Glob. Food Secur. 2021, 28, 100480. [CrossRef]

38. Vlaic, R.A.; Muressan, C.C.; Muste, S.; Muressan, A.; Muresan, V.; Suharoschi, R.; Petru st, G.; Mihai, M. Food Fortification through Innovative Technologies. In Food Engineering; IntechOpen: London, UK, 2019; p. 177.

39. White, P.J.; Broadley, M.R. Biofortifying crops whith essential mineral elements. Trends Plant Sci. 2005, 10, 586-593. [CrossRef] [PubMed]

40. Broadley, M.R.; Alcock, J.; Alford, J.; Cartwright, P.; Foot, I.; Fairweather-Tait, S.J.; Hart, D.J.; Hurst, R.; Knott, P.; McGrath, S.P.; et al. Selenium biofortification of high-yielding winter wheat (Triticum aestivum L.) by liquid or granular Se fertilization. Plant Soil 2010, 332, 5-18. [CrossRef]

41. Cakmak, I. Enrichment of cereal grains with zinc: Agronomic or genetic biofortification? Plant Soil 2008, 302, 1-17. [CrossRef]

42. Bouis, H.E.; Saltzman, A. Improving nutrition through biofortification: A review of evidence from HarvestPlus, 2003 through 2016. Glob. Food Secur. 2017, 12, 49-58. [CrossRef] 
43. Alfthan, G.; Eurola, M.; Ekholm, P.; Venäläinen, E.R.; Root, T.; Kork-alainen, K.; Hartikainen, H.; Salminen, P.; Hietaniemi, V.; Aspila, A.; et al. Effects of nationwide addition of selenium to fertilizers on foods, and animal and human health in Finland: From deficiency to optimal selenium status of the population. J. Trace Elem. Med. Biol. 2015, 31, 142-147. [CrossRef]

44. Ministry of Agriculture, Livestock and Supply Normative instruction. Rules on Definitions, Requirements, Specifications, Guarantees, Product Registration, Authorizations, Packaging, Labeling, Tax Documents, Advertisements and Tolerances of Fertilizers Are Established Minerals Intended for Agriculture. No. 46 of 22 November 2016. Available online: http: / / www.agricultura.gov.br/assuntos/insumos-agropecuarios/insumos-agricolas/fertilizantes/legislacao/in-46-de-22-1 1-2016-fert-minerais-dou-7-12-16.pdf (accessed on 14 January 2021).

45. De lima Lessa, J.H.; Araujo, A.M.; Ferreira, L.A.; Junior, E.C.; De Oliveira, C.; Corguinha, A.P.; Martins, F.A.D.; Carvalho, H.W.P.; Guilherme, L.R.G.; Lopes, G. Agronomic biofortification of rice (Oryza sativa L.) with selenium and its effect on element distributions in biofortified grains. Plant Soil 2019, 444, 331-342. [CrossRef]

46. Zou, C.; Du, Y.; Rashid, A.; Ram, H.; Savasli, E.; Pieterse, P.J.; Ortiz-Monasterio, I.; Yazici, A.; Kaur, C.; Mahmood, K.; et al. Simultaneous biofortification of wheat with zinc, iodine, selenium, and iron through foliar treatment of a micronutrient cocktail in six countries. J. Agric. Food Chem. 2019, 67, 8096-8106. [CrossRef]

47. Haug, A.; Graham, R.D.; Christophersen, O.A.; Lyons, G.H. How to use the world's scarce selenium resources efficiently to increase the selenium concentration in food. Microb. Ecol. Health Dis. 2017, 19, 209-228. [CrossRef]

48. Hawkesford, M.J.; Zhao, F.J. Strategies for increasing the selenium content of wheat. J. Cereal Sci. 2007, 46, 282-292. [CrossRef]

49. Święcicki, W.K.; Surma, M.; Koziara, W.; Skrzypczak, G.; Szukała, J.; Bartkowiak-Broda, I.; Zimny, J.; Banaszak, Z.; Marciniak, K. Modern technologies in plant production-Friendly to humans and the environment. Pol. J. Agron. 2011, 7, 102-112. (In Polish)

50. Wang, M.; Ali, F.; Wang, M.; Quang, T.D.; Zhou, F.; Bañuelos, G.S.; Liang, D. Understanding boosting selenium accumulation in wheat (Triticum aestivum L.) following foliar selenium application at different stages, forms, and doses. Environ. Sci. Pollut. Res. 2020, 27, 717-728. [CrossRef] [PubMed]

51. Acuña, J.J.; Jorquera, M.A.; Barra, P.J.; Crowley, D.E.; de la Luz Mora, M. Selenobacteria selected from the rhizosphere as a potential tool for Se biofortification of wheat crops. Biol. Fertil. Soils 2013, 49, 175-185. [CrossRef]

52. Lidon, F.C.; Oliveira, K.; Ribeiro, M.M.; Pelica, J.; Pataco, I.; Ramalho, J.C.; Leitão, A.E.; Almeida, A.S.; Campos, P.S.; RibeiroBarros, A.I.; et al. Selenium biofortification of rice grains and implications on macronutrients quality. J. Cereal Sci. 2018, 81, 22-29. [CrossRef]

53. Laurie, S.; Faber, M.; Adebola, P.; Belete, A. Biofortification of sweet potato for food and nutrition security in South Africa. Food Res. Int. 2015, 76, 962-970. [CrossRef]

54. Mechora, Š.; Germ, M.; Stibilj, V. Selenium compounds in selenium-enriched cabbage. Pure Appl. Chem. 2012, 84, 259-268. [CrossRef]

55. Bañuelos, G.S. Irrigation of broccoli and canola with boron and selenium-laden effluent. J. Environ. Qual. 2002, 31, 1802-1808. [CrossRef]

56. Skoczylas, Ł.; Tabaszewska, M.; Smoleń, S.; Słupski, J.; Liszka-Skoczylas, M.; Barański, R. Carrots (Daucus carota L.) Biofortified with Iodine and Selenium as a Raw Material for the Production of Juice with Additional Nutritional Functions. Agronomy 2020, 10, 1360. [CrossRef]

57. Rahman, M.M.; Erskine, W.; Zaman, M.S.; Thavarajah, P.; Thavarajah, D.; Siddique, K.H.M. Selenium biofortification in lentil (Lens culinaris Medikus subsp. culinaris): Farmers' field survey and genotype $\times$ environment effect. Food Res. Int. 2013, 54, 1596-1604. [CrossRef]

58. Motesharezadeh, B.; Ghorbani, S.; \& Alikhani, H.A. The effect of selenium biofortification in alfalfa (Medicago sativa). J. Plant Nutr. 2020, 43, 240-250. [CrossRef]

59. Dinh, Q.T.; Cui, Z.; Huang, J.; Tran, T.A.T.; Wang, D.; Yang, W.; Zhou, F.; Wand, M.; Yu, D.; Liang, D. Selenium distribution in the Chinese environment and its relationship with human health: A review. Environ. Int. 2018, 112, 294-309. [CrossRef] [PubMed]

60. Gerla, P.; Sharif, M.; Korom, S. Geochemical processes controlling the spatial distribution of selenium in soil and water, west central South Dakota, USA. Environ. Earth Sci. 2011, 62, 1551-1560. [CrossRef]

61. Dhillon, K.S.; Dhillon, S.K. Selenium concentrations of common weeds and agricultural crops grown in the seleniferous soils of northwestern India. Sci. Total Environ. 2009, 407, 6150-6156. [CrossRef] [PubMed]

62. Dong, Z.; Liu, Y.; Dong, G.; Wu, H. Effect of boiling and frying on the selenium content, speciation, and in vitro bioaccessibility of selenium-biofortified potato (Solanum tuberosum L.). Food Chem. 2021, 348, 129150. [CrossRef]

63. Ros, G.; Rotterdam, A.; Bussink, D.; Bindraban, P. Selenium fertilization strategies for bio-fortification of food: An agro-ecosystem approach. Plant Soil 2016, 404, 99-112. [CrossRef]

64. Neal, R.H.; Sposito, G.; Holtzclaw, K.M.; Traina, S.J. Selenite adsorption on alluvial soils: Soil Composition and pH effects. Soil Sci. Soc. Am. J. 1987, 51, 1161-1165. [CrossRef]

65. Li, H.F.; McGrath, S.P.; Zhao, F.J. Selenium uptake, translocation and speciation in wheat supplied with selenate or selenite. New Phytol. 2008, 178, 92-102. [CrossRef]

66. Manojlović, M.S.; Lončarić, Z.; Cabilovski, R.R.; Popović, B.; Karalić, K.; Ivezić, V.; Ademi, A.; Singh, B.R. Biofortification of wheat cultivars with selenium. Acta Agric. Scand. Sect. B Soil Plant Sci. 2019, 69, 715-724. [CrossRef]

67. Kashin, V.K.; Shubina, O.I. Biological effect and selenium accumulation in wheat under conditions of selenium deficient biogeochemical province. Chem. Sustain. Dev. 2011, 19, 145-150. 
68. Nawaz, F.; Ashraf, M.Y.; Ahmad, R.; Waraich, E.A.; Shabbir, R.N.; Bukhari, M.A. Supplemental selenium improves wheat grain yield and quality through alterations in biochemical processes under normal and water deficit conditions. Food Chem. 2015, 175, 350-357. [CrossRef] [PubMed]

69. Lara, T.S.; de Lima Lessa, J.H.; de Souza, K.R.D.; Corguinha, A.P.B.; Martins, F.A.D.; Lopes, G.; Guilherme, L.R.G. Selenium biofortification of wheat grain via foliar application and its effect on plant metabolism. J. Food Compos. Anal. 2019, 81, 10-18. [CrossRef]

70. Ekanayake, L.J.; Tharavarajah, D.; Vial, E.; Schatz, B.; McGee, R.; Thavarajah, P. Selenium fertilization on lentil (Lens culinaris Medikus) grain yield, seed selenium concentration, and antioxidant activity. Field Crop. Res. 2015, 177, 9-14. [CrossRef]

71. Ramkissoon, C. Selenium Dynamics in Cereal Biofortification: Optimising Fertiliser Strategies and Assessing Residual Fate. Ph.D. Thesis, University of Adelaide, Adelaide, Australia, 2020. Available online: https://digital.library.adelaide.edu.au/dspace/ handle/2440/126970 (accessed on 10 January 2021).

72. Ducsay, L.; Ložek, O.; Varga, L. The influence of selenium soil application on its content in spring wheat. Plant Soil Environ. 2009, 55, 80-84. [CrossRef]

73. Grant, C.A.; Buckley, W.T.; Wu, R. Effect of selenium fertilizer source and rate on grain yield and selenium and cadmium concentration of durum wheat. Can. J. Plant Sci. 2007, 87, 703-708. [CrossRef]

74. Wan, J.; Zhang, M.; Adhikari, B. Advances in selenium-enriched foods: From the farm to the fork. Trends Food Sci. Technol. 2018, 76, 1-5. [CrossRef]

75. Kottek, M.; Grieser, J.; Beck, C.; Rudolf, B.; Rubel, F. World map of the Köppen-Geiger climate classification updated. Meteorol. Z. 2006, 15, 259-263. [CrossRef]

76. Working Group World Reference Base for Soil Resources. The International Union of Soil Sciences. International Soil Classification System for Naming Soils and Creating Legends for Soil Maps. Available online: http:/ /www.fao.org/soils-portal/data-hub/soilclassification/world-reference-base/en/ (accessed on 12 December 2020).

77. Radawiec, A.; Szulc, W.; Rutkowska, B. Selenium Biofortification of Wheat as a Strategy to Improve Human Nutrition. Agriculture 2021, 11, 144. [CrossRef]

78. British Standard ISO 11466. Available online: https:/ / www.iso.org/standard/19418.html (accessed on 20 January 2021).

79. Norm, P. PN-R-04013: 1988. Chemical and Agricultural Analysis of Plants. Determination of Air-Dry and Dry Mass; Polish Committee for Standardization: Warsaw, Poland, 1988.

80. Lazo-Vélez, M.A.; Chávez-Santoscoy, A.; Serna-Saldivar, S.O. Selenium-enriched breads and their benefits in human nutrition and health as affected by agronomic, milling, and baking factors. Cereal Chem. 2015, 92, 134-144. [CrossRef]

81. White, P.J.; Bowen, H.C.; Parmaguru, P.; Fritz, M.; Spracklen, W.P.; Spiby, R.E.; Meacham, M.C.; Mead, A.; Harriman, M.; Trueman, L.J.; et al. Interactions between selenium and sulphur nutrition in Arabidopsis thaliana. J. Exp. Bot. 2004, 55, $1927-1937$. [CrossRef] [PubMed]

82. Nawaz, F.; Ashraf, M.Y.; Ahmad, R.; Waraich, E.A.; Shabbir, R.N.; Hussain, R.A. Selenium supply methods and time of application influence spring wheat (Triticum aestivum L.) yield under water deficit conditions. J. Agric. Sci. 2017, 155, 643-656. [CrossRef]

83. Curtin, D.; Hanson, R.; Van Der Weerden, T.J. Effect of selenium fertiliser formulation and rate of application on selenium concentrations in irrigated and dryland wheat (Triticum aestivum). N. Z. J. Crop Hortic. Sci. 2008, 36, 1-7. [CrossRef]

84. De Vita, P.; Platani, C.; Fragasso, M.; Ficco, D.B.M.; Colecchia, S.A.; Del Nobile, M.A.; Padalino, L.; Di Gennaro, S.; Petrozza, A. Selenium-enriched durum wheat improves the nutritional profile of pasta without altering its organoleptic properties. Food Chem. 2017, 214, 374-382. [CrossRef] [PubMed]

85. Tan, J.A. The Atlas of Endemic Diseases and Their Environment; Science Press: Beijing, China, 1989.

86. Kaur, N.; Sharma, S.; Kaur, S.; Nayyar, H. Selenium in agriculture: A nutrient or contaminant for crops? Arch. Agron. Soil Sci. 2014, 60, 1593-1624. [CrossRef]

87. Rodrigo, S.; Santamaria, O.; Poblaciones, M.J. Selenium application timing: Influence in wheat grain and flour selenium accumulation under mediterranean conditions. J. Agric. Sci. 2014, 6, 23. [CrossRef]

88. Curtin, D.; Hanson, R.; Lindley, T.N.; Butler, R.C. Selenium concentration in wheat (Triticum aestivum) grain as influenced by method, rate, and timing of sodium selenate application. N. Z. J. Crop Hortic. Sci. 2006, 34, 329-339. [CrossRef]

89. Ngigi, P.B.; Lachat, C.; Masinde, P.W.; Du Laing, G. Agronomic biofortification of maize and beans in Kenya through selenium fertilization. Environ. Geochem. Health 2019, 41, 2577-2591. [CrossRef]

90. Xia, Q.; Yang, Z.P.; Xue, N.W.; Dai, X.J.; Zhang, X.; Gao, Z.Q. effect of foliar application of selenium on nutrient concentration and yield of colored-grain wheat in China. Appl. Ecol. Environ. Res. 2019, 17, 2187-2202. [CrossRef]

91. Reis, H.P.G.; Barcelos, J.P.Q.; Junior, E.F.; Santos, E.F.; Silva, V.M.; Moraes, M.F.; Putti, F.F.; Reis, A.R. Agronomic biofortification of upland rice with selenium and nitrogen and its relation to grain quality. J. Cereal Sci. 2018, 79, 508-515. [CrossRef]

92. Hartikainen, H. Biogeochemistry of selenium and its impact on food chain quality and human health. J. Trace Elem. Med. Biol. 2005, 18, 309-318. [CrossRef] [PubMed]

93. Bañuelos, G.S.; Freeman, J.; Arroyo, I. Accumulation and speciation of selenium in biofortified vegetables grown under high boron and saline field conditions. Food Chem. X 2020, 5, 100073. [CrossRef] 